\title{
Familial Scheuermann disease: a genetic and linkage study
}

\author{
Louise McKenzie, D Sillence
}

\begin{abstract}
Scheuermann juvenile kyphosis or Scheuermann disease is the most frequent cause of kyphosis in adolescence. However, the natural history and genetic basis is still unknown. Reports of identical radiological changes in monozygotic twins, sib recurrence, and transmission over three generations suggest underlying heritability. In this study, 12 probands were referred to us. Upon radiological examination of the proband's parents and sibs, seven were shown to have familial Scheuermann disease with an autosomal dominant pattern of inheritance. Of the remaining five probands, four had chromosomal anomalies. The three largest pedigrees were subjected to linkage analysis with three candidate genes: Duffy, COL1A1, and COL1A2. Linkage of Scheuermann disease was excluded with Duffy (lod score $=-2 \cdot 195$ at $\theta=0 \cdot 10)$ and COL1A2 (lod score $=-2.750$ at $\theta=0.05$ ) in these families.
\end{abstract}

Scheuermann juvenile kyphosis or Scheuermann disease is the most frequent cause of kyphosis during adolescence ${ }^{1}$ with a population prevalence of approximately $8.3 \% .^{2}$ It is a progressive disorder with onset in late childhood or early adolescence and has been reported to occur more frequently in boys than girls. Scheuermann disease is characterised by lumbar or thoracic kyphosis or both (fig 1), back pain, and a variety of vertebral changes including wedging, end plate irregularity, narrowing of disc spaces, Schmorl's nodes, and detached epiphyseal rings (fig 2). The natural history and genetic basis for this disorder has yet to be elucidated. Almost complete identity of radiological changes in monozygotic twins suffering from Scheuermann disease suggests there is a major heritable contribution. ${ }^{3} \mathrm{~A}$ number of reports support autosomal dominant inheritance of this disease in some families. ${ }^{2-6}$ In the present study, 12 probands with diagnosed Scheuermann disease were referred. Upon radiological examination of the proband's parents and sibs, it was established that there was a familial incidence of the disease in seven families. These families were investigated further and an autosomal dominant form of inheritance was probable in all seven. In order to elucidate the genetic basis of Scheuermann disease in these families, several candidate genes were selected for linkage studies.

In the three generation family reported by Kelwalaramani et $a l,{ }^{4}$ Scheuermann disease cosegregated with Charcot-Marie-Tooth neuropathy (CMT) in an autosomal dominant pattern. Some forms of CMT have been localised to centromeric chromosome 1 markers including the Duffy blood group (1p2-1q2 $)^{7-9}$ with a combined maximum lod score of 7.08 at $\theta=0 \cdot 1 .^{10}$ To investigate whether Scheuermann disease could also be localised to chromosome 1 , linkage studies were performed between the three pedigrees described in this study and Duffy. Additionally, histological studies have shown defective collagen fibre formation within the cartilagenous end plates of vertebral bodies in persons suffering from Scheuermann disease, ${ }^{11} 12$ suggesting that a defect may exist in collagen biosynthesis. Defects in type I collagen have been shown to be responsible for several of the variants of osteogenesis imperfecta $^{13-15}$ and Ehlers-Danlos syndrome type VIIIA. ${ }^{16}$ Type II collagen has also been implicated in other connective tissue diseases such as Stickler's syndrome, ${ }^{17}$ spondyloepiphseal dysplasia ${ }^{18}$ and primary osteoarthritis associated with mild chondrodysplasia. ${ }^{19}$ As Scheuermann disease is a connective tissue disorder with defective collagen fibre formation, COL1A1 and COL1A2, which code for

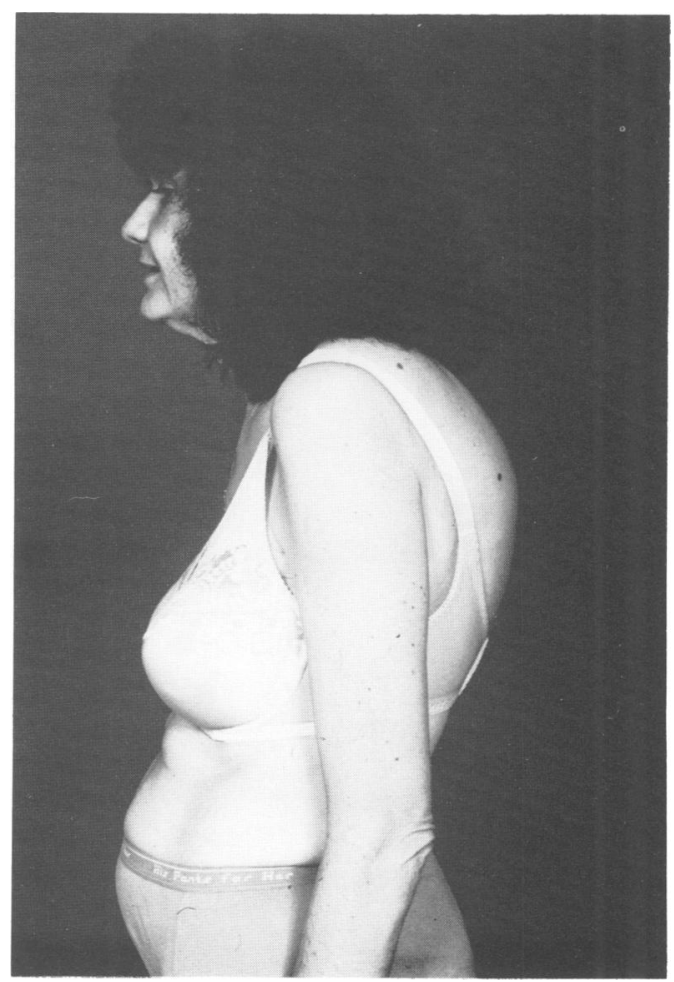

Figure 1 Lateral truncal view of 45 year old proband in family 1 with thoracic kyphosis caused by

Scheuermann disease. 


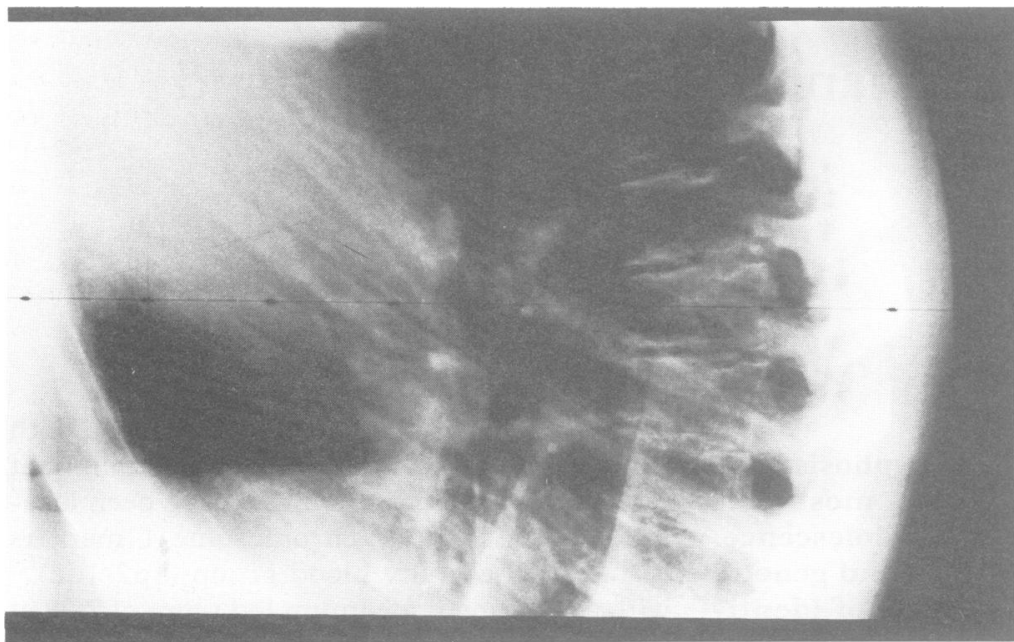

Figure 2 Lateral spine radiograph of a 14 year old boy showing some radiological features of Scheuermann disease including irregular end plates and vertebral wedging.

the two subunits of human collagen type I, pro $\alpha 1(\mathrm{I})$ and pro $\alpha 2(\mathrm{I})$, were considered appropriate candidate genes for linkage studies.

\section{Materials and methods \\ FAMILIES}

Twelve subjects with Scheuermann disease, selected for a suspected family history or additional genetic anomaly, were referred for investigation. Blood samples were collected and a complete family pedigree and history was taken. Upon radiological examination of each proband's parents and sibs, seven families were shown to have familial Scheuermann disease. From these seven families blood was collected from 98 subjects, 49 of whom were affected. Radiographs were obtained from each family member and interpreted independently by a radiologist with special expertise in bone dysplasias. All bloods were typed for Duffy (Fy), ABO, Rh, MNS, P, Kell, Le, Lu, and JK to confirm parentage. Subjects were diagnosed as having Scheuermann disease if they showed radiological evidence of vertebral wedging, irregular end plates, Schmorl's nodes, narrowing of disc spaces, detached epiphyseal rings, and lumbar or thoracic kyphosis.

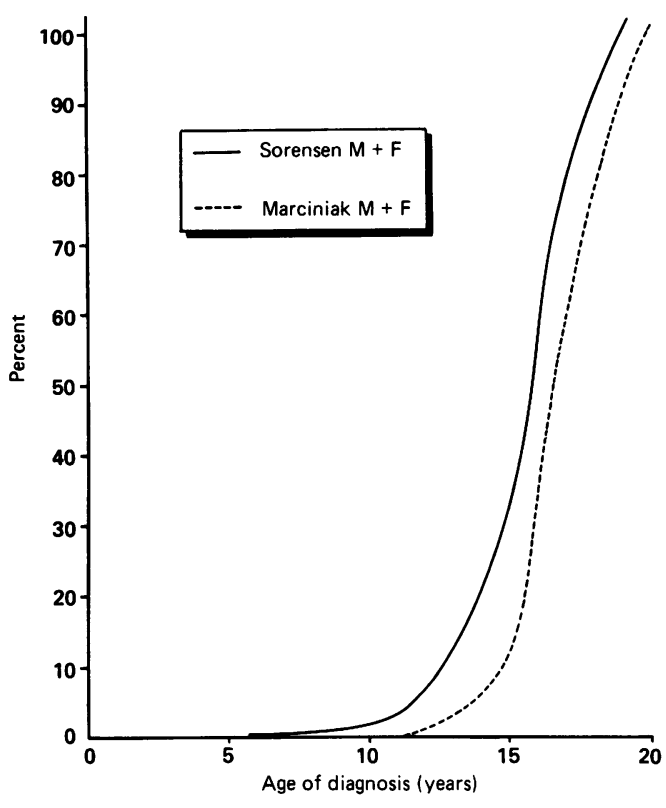

Figure 3 Age of diagnosis (age penetrance) curves drawn from population screening studies of Sorenson ${ }^{24}$ and Marciniak.

DNA EXTRACTION, SOUTHERN BLOTTING, AND HYBRIDISATION

DNA was extracted from heparinised whole blood, digested with restriction enzymes according to the manufacturer's directions, and run on $0.8 \%$ agarose gels using standard methods. ${ }^{20}$ DNA was transferred to Hybond$\mathrm{N}$ membranes (Amersham Aust Pty Ltd) and hybridisations were performed as suggested by the supplier, using $\left({ }^{32} \mathrm{P}\right)$-dCTP nick translated probes.

\section{PROBES}

The probe p2FC.6 was obtained from P Tsipouras. ${ }^{21}$ It spans an $R s a I$ generated polymorphism from near the $5^{\prime}$ end of human COL1A1. The probe $\mathrm{NJ} / 4.1$ was also supplied by $P$ Tsipouras $^{22}$ and spans a StuI polymorphism from near the $3^{\prime}$ end of the human COL1A2 gene. NJ/4.1 also detects an MspI RFLP. However, this polymorphism was not informative for any of the families tested in this study.

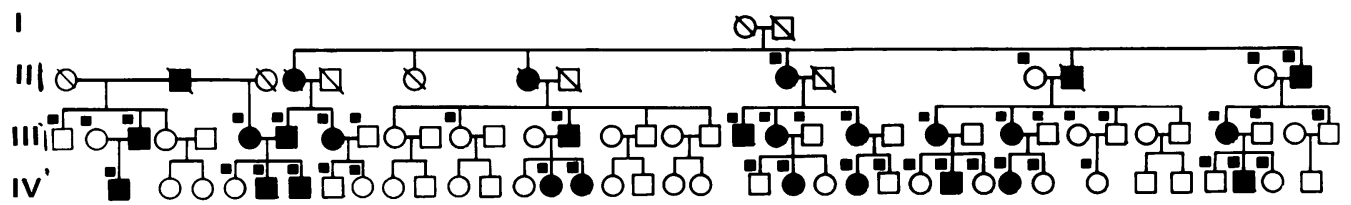

Family 2

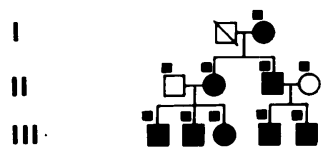

Family 3

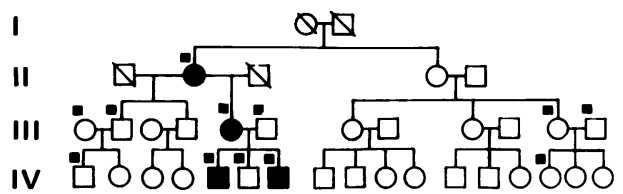

Figure 4 Pedigrees of families 1, 2, and 3. Subjects from whom DNA and $x$ rays were analysed are marked with a black square. 
Table 1 Linkage results of Scheuermann disease and Duffy lod scores with $\theta_{\mathrm{m}}=\theta_{\mathrm{f}}$.

\begin{tabular}{lcccccc}
\hline \multirow{2}{*}{$\begin{array}{l}\text { Pedigree } \\
\text { designation }\end{array}$} & 0 & 0.001 & 0.05 & 0.10 & 0.15 & \multicolumn{1}{c}{0.20} \\
\cline { 2 - 7 } & -1.267 & -1.141 & -0.123 & 0.048 & 0.103 & 0.110 \\
1 & $-\infty$ & -3.493 & -1.141 & -0.663 & -0.412 & -0.258 \\
2 & $-\infty$ & -5.640 & -2.212 & -1.580 & -1.201 & -0.925 \\
3 & $-\infty$ & -10.274 & -3.476 & -2.195 & -1.510 & -1.073 \\
\hline
\end{tabular}

\section{LINKAGE ANALYSIS}

The computer program LIPED ${ }^{23}$ was used for calculation of lod scores between the Scheuermann disease locus and individual markers at various recombination fractions. The maximum gene frequency for Scheuermann disease was estimated at $0 \cdot 04$. Age of onset was also included as a variable (fig 3 ).

\begin{abstract}
Results
Twelve probands were referred with diagnosed Scheuermann disease. Blood samples were collected from all 12 and extensive family histories were taken. After radiological examination it was shown that seven of the families investigated had familial Scheuermann disease. Radiographs were not reviewed for any family members under 8 years. Of the remaining five probands, four had chromosome anomalies. One patient had a chromosome 2 anomaly $(46, \mathrm{XX}, 2 \mathrm{q}+)$ and the remaining three had sex chromosome anomalies $(47, \mathrm{XYY}, 47, \mathrm{XXY}$, and $45, \mathrm{XO})$. Additionally, two affected subjects from family 3 were mentally retarded males (with no dysmorphology).
\end{abstract}

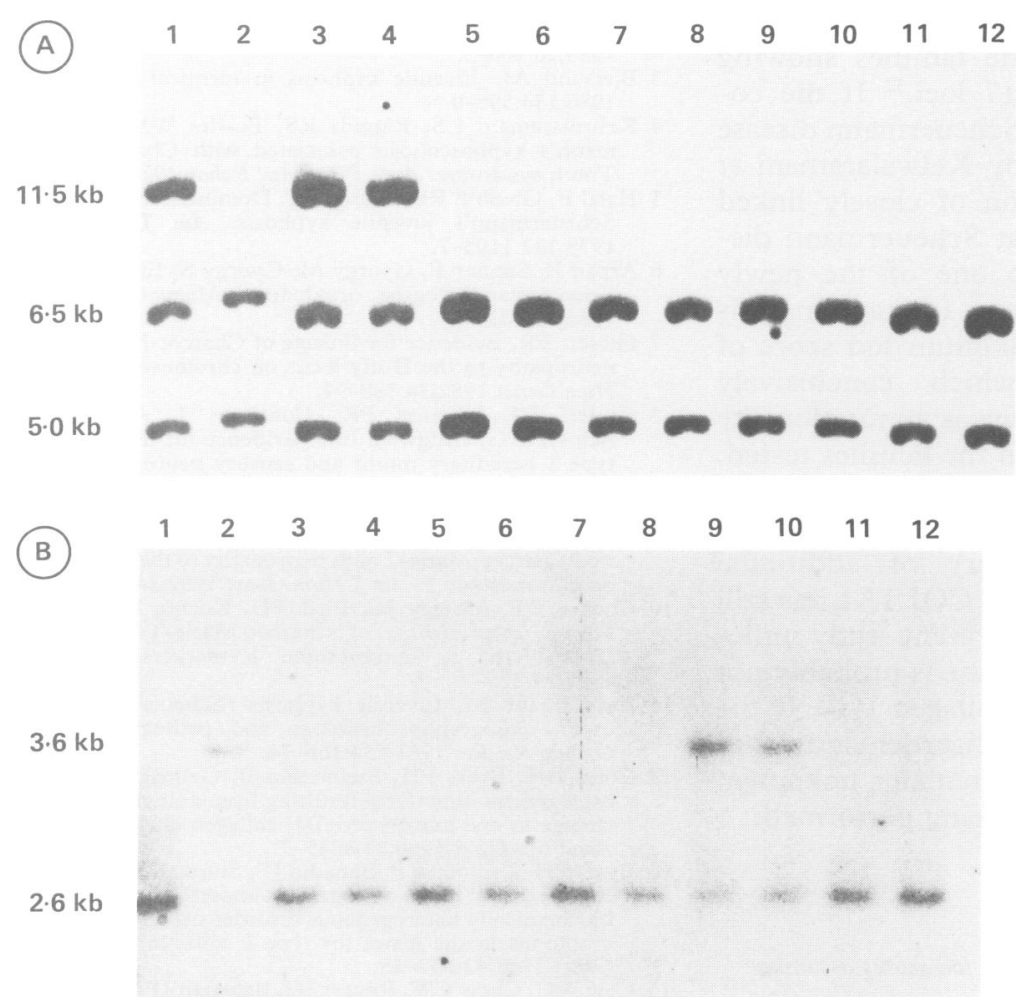

Figure 5 RFLPs used in Scheuermann disease studies. (A) COL1A2 StuI RFLP. Homozygotes have either $11.5 \mathrm{~kb}$ (data not shown) or 6.5/5 kb (lanes 2, 5-12) bands. Heterozygotes show all three bands (lanes 1,3,4). (B) COL1A1 RsaI RFLP. Homozygotes have either a $2.6 \mathrm{~kb}$ (lanes $1,3-8,11,12$ ) or a $3.6 \mathrm{~kb}$ (lane 2) band. Heterozygotes show both bands (lanes 9,10$)$.
Of the 49 affected subjects, 26 were male and 23 were female. $\chi^{2}$ analysis showed there was no statistical difference between the number of affected males and females $\left(\chi^{2}=0.09, \mathrm{p}<0.05\right)$.

All seven families with familial disease showed a pattern of autosomal dominant inheritance with the possible exception of two of the smaller families, where $\mathrm{X}$ linked inheritance could not be ruled out. Three multigenerational families with sufficient family members consenting to radiographic and DNA studies to allow inclusion in the study were suitable for linkage analysis (fig 4). Linkage to Duffy, COL1A1, and COL1A2 was investigated.

The frequency of the two common Duffy (Fy) alleles $a$ and $b$ is 0.45 and 0.55 respectively. All three families were informative for Duffy. Families 2 and 3 showed non-linkage to Duffy at $5 \mathrm{cM}$ or less $(Z=-2.212$ at $\theta=0.005$ ). Lod scores for family 1 showed only probable non-linkage giving $Z=-1.267$ at $0 \mathrm{cM}$. However, the combined maximum lod scores of all three families showed non-linkage with Duffy at $10 \mathrm{cM}$ or less $(Z=-2.195$ at $\theta=0.01$ ) (table 1 ).

The probe NJ1/4.1 contains $4.1 \mathrm{~kb}$ of human CDNA from near the $3^{\prime}$ end of the pro $\alpha 2(\mathrm{I})$ collagen gene (COL1A2). NJ1/4.1 identifies a StuI RFLP. Homozygotes for the + allele show an $11.5 \mathrm{~kb}$ band and homozygotes for the - allele show bands of $6.5 \mathrm{~kb}$ and $5 \mathrm{~kb}$. Heterozygotes show all three bands (fig 5A). The frequencies of the + and the alleles are 0.918 and 0.082 respectively. Family 3 was not informative giving a lod score of -0.756 at $0 \mathrm{cM}$. Family 1 , however, showed non-linkage to pro $\alpha 2(\mathrm{I})$ at $5 \mathrm{cM}$ (lod score $=$ -2.248 at $\theta=0.05$ ). Combining the maximum lod scores of families 1 and 2 excluded linkage with pro $2(\mathrm{I})$ at $5 \mathrm{cM}$ or less $(Z=-2.750$ at $\theta=0.05$ ) (table 2).

The probe p25C.6 contains $1.8 \mathrm{~kb}$ of human cDNA from near the $5^{\prime}$ end of the proal(I) collagen gene (COL1A1). p2FC. 6 identifies an RsaI RFLP. Homozygotes for the + allele show a $2 \cdot 6 \mathrm{~kb}$ band and homozygotes for the allele show a $3.6 \mathrm{~kb}$ band. Heterozygotes show both bands (fig 5B). The frequencies for the + and - alleles are 0.86 and 0.14 respectively. Probably because of the low frequency of the - allele generated by p2FC.6 (PIC $=0.21$ ), neither family 2 nor 3 was informative for COL1A1 polymorphism. The lod scores generated by linkage analysis with family 1 showed only probably non-linkage to COL1A1 $(Z=-1.321$ at $\theta=0)$ (table 3 ).

Autoradiographs of Southern blots of both the families' DNA and DNA from the remaining five probands not included in the collagen type I linkage studies showed only the expected RFLPs indicating that in these cases Scheuermann disease was not the result of a major deletion or insertions in the regions spanned by either $\mathrm{NJ} / 4.1$ or p2FC. 6 .

\section{Discussion}

Scheuermann disease has received a large amount of attention in medical publications of recent years. Primarily these reports have 
Table 2 Linkage results of Scheuermann disease and COLIA2 lod scores assuming $\theta_{\mathrm{m}}=\theta_{\mathrm{f}}$.

\begin{tabular}{lcccccc}
\hline \multirow{2}{*}{$\begin{array}{l}\text { Pedigree } \\
\text { designation }\end{array}$} & 0 & 0.001 & 0.05 & 0.10 & 0.15 & 0.20 \\
\cline { 2 - 7 } & $-\infty$ & -4.812 & -2.248 & -1.486 & -0.994 & -0.648 \\
1 & -0.756 & -0.748 & -0.502 & -0.367 & -0.280 & -0.218 \\
2 & $-\infty$ & -5.560 & -2.750 & -1.853 & -1.274 & -0.866 \\
\hline
\end{tabular}

centred on clinical descriptions, ${ }^{26-28}$ lifestyle influences on the disease process, ${ }^{29}$ and medical management strategies. ${ }^{30}$ While Scheuermann disease is recognised as a discrete disease and medical practitioners are aware of both the negative cosmetic and clinical effects of this disorder, the natural history and genetic basis is still unknown.

While this study cannot be a population genetic study because of the biased ascertainment of the probands, it shows that radiological evidence of Scheuermann disease may be more frequent in families than previously suspected from the frequency of Scheuermann kyphosis.

The results of this study do not support previous reports of Scheuermann disease affecting more males than females. It is possible that males generally play more contact sport or are involved in more labour intensive work than females. This may lead to an increased incidence of back pain and hence more frequent presentation of males to orthopaedic clinics.

The results from this study excluded linkage of the Scheuermann disease locus to the centromeric chromosome 1 marker, Duffy. It has recently been shown that CMT is a heterogeneous disorder ${ }^{31}$ with some families showing linkage to chromosome 17 loci. $^{32}$ If the cosegregation of CMT and Scheuermann disease in the family described by Kelwalaramani $e t$ $a l^{4}$ is a result of mutation of closely linked genes, then it may be that Scheuermann disease can be localised to one of the newly emerging CMT localisations. Linkage analysis using $\mathrm{NJ} 1 / 4.1$ gave a maximum lod score of -2.750 at $\theta=0.05$, which conclusively excluded the COL1A2 gene as a mutation site in Scheuermann disease in the families tested.

Owing to lack of highly polymorphic sites in COL1A1, lod scores only indicated probable non-linkage. The discovery of additional highly polymorphic sites in COL1A1 has still to be resolved. While the present study indicates that Scheuermann disease is probably not the result of a defect in collagen type I, the relationship between this disorder and other fibrillar collagen genes still remains unknown. This analysis is currently being performed.

Table 3 Linkage results of Scheuermann disease and COL1A1 lod scores assuming $\theta_{\mathrm{m}}=\theta_{\mathrm{r}}$.

\begin{tabular}{lcccccc}
\hline \multirow{2}{*}{$\begin{array}{l}\text { Pedigree } \\
\text { designation }\end{array}$} & 0 & 0.001 & 0.05 & 0.10 & 0.15 & 0.20 \\
\cline { 2 - 7 } & -1.321 & -1.308 & -0.848 & -0.571 & -0.386 & -0.254 \\
\hline 1 & &
\end{tabular}

We have reported four subjects who have Scheuermann disease and chromosome anomalies, three of whom had sex chromosome anomalies. In a survey performed by Muller and Gschwend, ${ }^{33} 10$ out of 22 cases of Turner's syndrome were shown to have Scheuermann disease. Additionally they presented a case report of a patient with both Klinefelter's syndrome and Scheuermann disease. As the clinical manifestations of Scheuermann disease coincide with puberty, it may be that Scheuermann disease is influenced by hormonal/developmental factors. Further studies of unselected groups of patients with sex chromosome aneuploidy are indicated to confirm the frequency of Scheuermann disease and XO, $X X Y$, and $X Y Y$ respectively. The subject with the chromosome 2 anomaly $(2 q+)$ was not available for further evaluation.

This work has enabled planned follow up studies of the cohort described in this report which will give important information pertaining to the natural history of Scheuermann disease.

We gratefully acknowledge Professor T K F Taylor and Dr J Cummine for referring patients, Dr K Kozlowski for expert radiological diagnosis, Dr J Donald and Dr D Ross for assistance with LIPED, and the Red Cross Blood Transfusion, Sydney for blood typing. Dr Petros Tsipouras kindly supplied the COL1A1 and COL1A2 probes used. This study was supported by a grant from SPINECARE.

1 Nielsen OG, Pilgaard P. Two hereditary spinal diseases producing kyphosis during adolescence. Acta Paediatr Scand 1987;76:133-6.

2 Findlay A, Conner AN, Connor JM. Dominant inheritance of Scheuermann's juvenile kyphosis. $\mathcal{f}$ Med Genet 1989;26:400-3.

3 Bjersand AJ. Juvenile kyphosis in identical twins. $A \mathcal{F R}$ 1980;134:598-9.

4 Kelwalaramani LS, Riggins RS, Fowler WM. Scheuermann's kyphoscoliosis associated with Charcot-MarieTooth syndrome. Arch Phys Med Rehab 1976;57:391-7.

5 Halal F, Gledhill RB, Fraser FC. Dominant inheritance of 1978;132:1105-7.

6 Arpad B, Sandor F, Gyorgy M, Gyorgy S, Erzsebet G. A Scheuermannbetegseg oroklodese. Magyar Traumatol 1986;29:163-7.

7 Giblett ER. Evidence for linkage of Charcot-Marie-Tooth neuropathy to the Duffy locus on chromosome 1 . Am $\mathcal{J}$ Hum Genet 1982;34:388-94.

8 Guiloff RJ, Thomas PK, Contreras J, Armitage S, Schwartz G, Sedgwick EM. Evidence for linkage of the type 1 hereditary motor and sensory neuropathy to the Duffy locus on chromosome 1. $\mathcal{F}$ Neurol Neurosurg Psychiatry 1982;45:669-74.

9 Stebbins NB, Conneally PM. Linkage of dominantly inherited Charcot-Marie-Tooth neuropathy to the Duffy locus on chromosome 1. Am f Hum Genet 1982;34:195A.

10 Chance DF, Murray JC, Bird TD, Kochin RS. Genetic linkage relationships of Charcot-Marie-Tooth disease (HMSN-Ib) to chromosome 1 markers. Neurology 1987;37:325-9.

11 Aufdermaur $M$. Juvenile kyphosis (Scheuermann's disease): radiography, histology and pathogenesis. Clin Orthop Rel Res 1981;154:166-74.

13 Cohn DH, Byers PH, Steinmann B, Gelinas RE. Lethal osteogenesis imperfecta resulting from a single nucleotide change in one human proaI(I) collagen allele. Proc Nat Acad Sci USA 1986;83:6045-7.

14 Byers PH, Tsipouras P, Bonadio JF, Starman BJ, Schwartz RC. Perinatal lethal osteogenesis imperfecta (OI type II): biochemically heterogeneous disorder usually due to new mutations in the genes for type I collagen. Am $\mathcal{F}$ Hum Genet 1988;42:237-48.

15 Cole WG, Chow CW, Rogers JG, Bateman JF. The clinical features of three babies with osteogenesis imperfecta resulting from the substitution of glycine by arginine in the proa I(I) chain of type I procollagen. $f$ Med Genet 1990;27:228-35.

16 Weil D, D'Alessio M, Ramirez F, et al. A base substitution in the exon of a collagen gene causes alternative splicing and generates a structurally abnormal polypeptide in a 
patient with Ehlers-Danlos syndrome type VII. EMBO $\mathcal{f}$ 989;8:1705-10

17 Francomano CA, Maumenee I, Liberfarb R, Pyeritz RE. Cosegregation of Stickler syndrome and type II collagen gene alleles. Cytogenet Cell Genet 1987;46:615.

18 Lee B, Vissing H, Ramirez F, Rogers D, Rimoin D. Identification of the molecular defect in a family with spondyloepiphyseal dysplasia. Science 1989;244:978-80.

19 Knowlton RG, Katzenstein PL, Moskowitz RW, et al. Genetic linkage of a polymorphism in the type II procolGen gene (Col 2Al) to primary osteoarthritis associated with mild chondrodysplasia. N Engl f Med 1990;322:52630 .

20 Sambrook J, Fritsch EF, Maniatis T. In: Nolan C, ed. Molecular cloning: a laboratory mamual. 2nd ed. Cold Spring Molecular cloning: a laboratory manual. 2nd ed. Cold Spring

21 Sykes B, Ogilvie D, Wordsworth P, Anderson D, Jones N. Osteogenesis imperfecta is linked to both type I collagen structural genes. Lancet 1986;ii:69-72.

22 Falk CT, Schwartz RC, Ramirez F, Tsipouras P. Use of molecular haplotypes specific for the human pro 2 (I) collagen gene in linkage analysis of the mild autosoma dominant forms of osteogenesis imperfecta. Am $\mathcal{F}$ Hum Genet 1986;38:269-79.

$23 \mathrm{Ott} \mathrm{J}$. Estimation of the recombination fraction in human pedigrees: efficient computation of the likelihood for human linkage studies. Am $\mathfrak{f}$ Hum Genet 1974;26:588-97.
24 Sorensen KH. Scheuermann's juvenile kyphosis. Copenhagen: Munksgaard, 1964

25 Marciniak R. In choroba Schevermanna: kyphosis dorsi juvenilis. Wroclaw: Ossolinevur, 1979.

26 Bradford DS, Brown DM, Moe JH, Winter RB, Jowsey J. Scheuermann's kyphosis: a form of osteoporosis? Clin Orthop Rel Res 1976;118:83-90.

27 Bradford DS. Vertebral osteochondrosis. Clin Orthop Rel Res 1981;158:83-90.

28 Ryan MD, Taylor TKF. Acute spinal cord compression in Scheuermann's disease. $\mathcal{f}$ Bone foint Surg $[\mathrm{Br}]$ 1982;64:409-12.

29 Blazek O, Streda A, Cernak V, Skallova O. The incidence of morbus Scheuermann in sportsmen. $\mathcal{f}$ Sports Med morbus Sche

30 Bradford DS, Moe JH, Montalvo FJ, Winter RB. Scheuermann's kyphosis and roundback deformity. $\mathcal{f}$ Bone foint Surg $[\mathrm{Am}] 1974,56: 740-58$

31 Griffiths LR, Zwi MB, McLeod JG, Nicholson GA. Chromosome 1 linkage studies in Charcot-Marie-Tooth neuropathy type 1. Am $\mathcal{F}$ Hum Genet 1988;42:756-71.

32 Vance JM, Nicholson GA, Yanaoka LH, et al. Linkage of Charcot-Marie-Tooth neuropathy la to chromosome 17 . Exp Neurol 1989;104:186-9.

33 Muller G, Gschwend N. Endokrine storungen und morbus Scheuermann. Arch Orthop Unfall-Chir 1969;65: $357-62$. 